Nalar: Jurnal Peradaban dan Pemikiran Islam

Volume 5 Nomor 1, Juni 2021

http://e-journal.iain-palangkaraya.ac.id/index.php/nalar

E-ISSN: 2598-8999, P-ISSN: 2597-9930

\title{
Ideologi Keagamaan, Partai Politik, dan Pendidikan Islam: Refleksi Pemikiran Hasan Al-Banna di Sekolah Islam Terpadu Ukhuwah Banjarmasin
}

\author{
Yunizar Ramadhani \\ Sekolab Tinggi Ilmu Tarbiyah Darul Hijrah, Martapura, Indonesia \\ ramadhani897@gmail.com
}

\begin{abstract}
Keywords :
Abstract

Hasan Al-Banna;

This study aims to analyze the relationship between Hasan Al-Banna's thoughts and the

Islamic Education; practice of Islamic education at Sekolah Islam Terpadu Ukhuwah Banjarmasin. This is a Integrated Islamic qualitative research by combining literature study and field study and conducted at that School Islamic school. The data is collected through observation, interviews and literature study. The analysis reveals that the of Islamic education at Sekolah Islam Terpadu Ukhuwah Banjarmasin not only has a relationship with Hasan Al-Banna's thoughts, but has an emotional and ideological connectedness to the Muslim Brotherhood and Partai Keadilan Sejabtera (PKS). In addition, the practice of Islamic education at the school has ideological and applicative relevance to Al-Banna's educational thinking. His thoughts become the ideological foundation of the school and then implemented in its curriculum and educational process. Specifically, the inspiration of the school's educational practice comes from the Tarbiyah movement of the Muslim Brotherhood. It can be concluded that Sekolah Islam Terpadu Ukhuwah Banjarmasin makes Al-Banna's religious ideology the foundation of its education, and, furthermore, is the actualization of the Tarbiyah Movement and the media for the educational actualization of Partai Keadilan Sejahtera (PKS).

Kata Kunci :
Hasan Al-Banna;
Pendidikan Islam;
Sekolah Islam
Terpadu

Abstrak

Kajian ini bertujuan menganalisis hubungan pemikiran Hasan Al-Banna dengan praktik pendidikan Islam di sekolah Islam terpadu Ukhuwah Banjarmasin. Jenis kajian ini adalah kualitatif dengan mengkombinasikan antara studi kepustakaan dan studi lapangan. Lokasi penelitian ini adalah sekolah Islam terpadu Ukhuwah Banjarmasin. Data diperoleh melalui observasi, wawancara, dan studi kepustakaan. Melalui analisis terhadap data yang diperoleh ditemukan bahwa praktik pendidikan Islam di sekolah Islam terpadu Ukhuwah Banjarmasin tidak hanya memiliki hubungan dengan pemikiran Hasan AlBanna, namun juga memiliki hubungan emosional dan ideologis dengan Ikhwanul Muslimin dan Partai Keadilan Sejabtera. Selain itu pendidikan Islam di sekolah Islam terpadu Ukhuwah Banjarmasin memiliki relevansi ideologis dan aplikatif dengan pemikiran pendidikan Hasan Al-Banna. Pada tataran ideologis, pemikiran Hasan AlBanna menjadi fondasi ideologi pendidikan di sekolah Islam terpadu Ukhuwah Banjarmasin. Sedangkan pada tataran aplikatif, pemikiran Hasan Al-Banna di implementasikan dalam praktik pendidikan dan kurikulum yang digunakan di sekolah Islam terpadu Ukhuwah Banjarmasin. Secara spesifik inspirasi praktik pendidikan di sekolah Islam terpadu Ukhuwah Banjarmasin bersumber dari gerakan tarbiyah Ikhwanul Muslimin. Berdasarkan temuan tersebut dapat disimpulkan bahwa pendidikan Islam di sekolah Islam terpadu Ukhuwah tidak sekadar menjadikan ideologi keagamaan Hasan Al-Banna sebagai fondasi pendidikan, namun juga merupakan aktualisasi gerakan tarbiyah Ikhwanul Muslimin dan media aktualisasi pendidikan bagi kader Partai Keadilan Sejabtera.

Article History : $\quad$ Received : 22-12-2020 $\quad$ Accepted : 06-07-2021
\end{abstract}




\section{PENDAHULUAN}

Saat ini sekolah-sekolah Islam begitu banyak jumlahnya di Indonesia. Sebagian besar sekolah Islam yang menjamur di daerah-daerah perkotaan itu memberikan pendidikan modern dengan nuansa dan nilai-nilai Islam bagi seluruh anak-anak didiknya. Kajian-kajian ilmiah menyebut kehadiran sekolah-sekolah tersebut tidak lepas dari pengaruh iklim reformasi di Indonesia di satu sisi dan bertumbuhnya kalangan kelas menengah muslim di sisi yang lain (Hefner 2009; Tayeb 2018). Setelah melewati periode yang suram bagi ideologi Islam sepanjang orde lama dan orde baru, terbukanya kebebasan pada era reformasi menjadi jalan kemunculan kelompok-kelompok Islam secara lebih luas. Dalam politik misalnya, kelompok-kelompok Islam yang dulunya terbungkam oleh pemerintahan represif orde baru hadir melalui partai-partai politik berasas Islam, seperti Partai Masyumi Baru, Partai Politik Islam Indonesia (PPII), Partai Bulan Bintang (PBB), dan Partai Keadilan (PK), yang kemudian menjadi Partai Keadilan Sejahtera (PKS) (Bubalo, Fealy, dan Mason 2008; Muhtadi 2012; Hadiz 2016).

Keadaan ini berdampak kepada segala bidang masyarakat muslim, termasuk pendidikan Islam. Sekolah-sekolah Islam swasta turut bermunculan, di mana yang paling menonjol di antaranya adalah sekolah Islam terpadu (SIT). Sekolah ini menjadikan Islam dan ilmu-ilmu keislaman dengan dilengkapi keterampilan modern sebagai poros dan kandungan pendidikan yang diberikan kepada anak didik. Pola pendidikan dan pengajaran yang penuh totalitas menjadi ciri khas dan penjelasan umum dari istilah terpadu dalam nomenklatur sekolah Islam terpadu, yaitu integrasi antara keimanan, intelektualitas, dan keterampilan dalam sajian pendidikannya. Hal ini terlihat subjek kajian ini, yaitu sekolah Islam terpadu Ukhuwah Banjarmasin yang tergabung dalam Jaringan Sekolah Islam Terpadu (JSIT). Sekolah Islam terpadu Ukhuwah terdiri atas lembaga-lembaga pendidikan Islam formal di bawah naungan Yayasan Ukhuwah dan termasuk dalam kelompok Sekolah Islam Terpadu Regional V wilayah Kalimantan (Jaringan Sekolah Islam Terpadu Indonesia 2021). Tahun 2013, sekolah Islam terpadu Ukhuwah adalah terbesar dan terfavorit di wilayah Kalimantan Selatan yang berada di bawah naungan Yayasan Ukhuwah yang memiliki lebih dari 1100 siswa dan 200 lebih guru dan karyawan.

Sekolah ini memiliki motto "Berakhlak, berprestasi, dan mandiri" (Sekolah Islam Terpadu Ukhuwah 2021). Motto ini ingin menggambarkan jiwa integral dan holistik dari pendidikan yang dilaksanakan di dalamnya. Motto itu merepresentasikan nilai-nilai dasar yang dianut sekolah Islam terpadu Ukhuwah dalam menjalankan aktivitas pendidikannya. Nilai-nilai tersebut tentu tidak akan muncul dalam benak pencetus dan pendiri sekolah tanpa dilandasi nilai-nilai ideologis yang telah terlebih dahulu dianut, dan hal ini merupakan suatu tindakan politis. Michael W. Apple (2019) mengutarakan “...education was not a neutral enterprise, that, by the very nature of the institution, the educator was involved, whether he or she was conscious of it or not, in a political act." Munculnya asumsi yang bisa saja mengaitkan eksistensi sekolah-sekolah Islam modern ini dengan ideologi tertentu tidak dapat dipungkiri. Akan tetapi, ruang lingkup kronologis dan kesejarahan tidak menjadi fokus utama kajian ini, melainkan lebih terfokus pada hubungn hubungan ideologis antara sekolah Islam terpadu dengan orientasi pemikiran tertentu. Berdasarkan penjajakan awal terhadap program dan kegiatan pendidikan Islam di sekolah Islam terpadu Ukhuwah Banjarmasin, terlihat adanya keterkaitan konsepsi pendidikan Hasan Al-Banna.

Hasan Al-Banna adalah pendiri kelompok revivalis-revolusionis Mesir yaitu Ikhwanul Muslimin. Al-Banna juga dapat dikatakan sebagai pemikir pendidikan Islam pada generasi revivalisme Islam (Suwito dan Fauzan 2005). Al-Banna memang tidak menyampaikan pemikirannya lewat tulisan-tulisannya, melainkan melalui aktualisasi gerakan Ikhwanul Muslimin sebagai gerakan politik dan pendidikan umat Islam. Pemikiran Al-Banna juga 
disampaikan melalui berbagai dokumentasi muridnya yang mengikuti kiprah Al-Banna bersama Ikhwanul Muslimin (Al-Qardhawi 2005). Meski demikian, Al-Banna menyinggung beberapa poin penting tentang pendidikan di dalam karyanya, seperti betapa pentingnya peran generasi muda dalam bidang dakwah dan tugas Ikhwanul Muslimin adalah menaruh kepercayaan pada gerakan dakwah generasi muda, membekalinya, dan memberikannya bimbingan (Al-Banna 1992). Selain itu dalam karya tersebut Al-Banna juga menyisipkan satu bab seruannya kepada para tentang pentingnya berdakwah dan elemen-elemen pendukung dalam berdakwah, seperti pembangunan diri dan akhlak (Al-Banna 1992).

Konsep tarbiyah Al-Banna berpijak pada konsepsi Islam yang menyeluruh (kaffah), yakni bahwa Islam tidak hanya dipandang sebagai agama, tetapi juga eksistensi sosial dan budaya yang terpatri dalam hukum, tata negara, ekonomi, politik, dan seni. Maka dari itu, pendidikan baginya tidak hanya terbatas satu aspek, melainkan seluruh aspek kehidupan manusia. Pada tataran ini Al Banna memandang bahwa pendidikan Islam tidak hanya terbatas pada aspek rohani atau akhlak saja, atau kemampuan intelektual, atau fisik, atau kemampuan sosial saja (Al-Qardhawi 2005). Pandangan Al-Banna yang menaruh perhatian pada seluruh aspek hidup manusia ini ditujukan untuk menyiapkan generasi muslim yang mampu menghadapi berbagai kondisi dan situasi yang dihadapi umat. Pandangan ini sangat dipengaruhi oleh konteks sosial-politik yang dihadapi masyarakat Mesir saat itu, di mana AlBanna menilai masyarakat Mesir berada di tengah-tengah pengaruh pola pikir Barat (Eropa). Pola-pola tarbiyah Al-Banna ini nampak terimplementasikan dalam ideologi dan penyelenggaraan pendidikan di sekolah Islam terpadu. Jika demikian, benarkah sekolah Islam terpadu mengambil dasar pemikiran bagi penyelenggaraan pendidikan dari Hasan Al- Banna, dan jika benar sejauh mana pemikiran pendidikannya menjadi pijakan bagi sekolah Islam terpadu?

Kajian terkait sekolah Islam Terpadu maupun pemikiran pendidikan Islam Hasan AlBanna pada dasarnya sudah pernah dilakukan sebelumnya. Suyatno (2013) dalam kajiannya menemukan bahwa sekolah Islam terpadu telah memberikan warna baru dalam perkembangan pendidikan Islam di Indonesia. Selain itu sekolah Islam terpadu berkontribusi dalam menampilkan corak baru dalam reislamisasi di Indonesia. Selain itu Djalaluddin (2015) dalam kajiannya menemukan bahwa terdapat tiga aspek yang saling terkait dalam pemikiran pendidikan Al-Banna yaitu akal, jasmani, dan hati. Ketiga aspek ini hanya dapat diperoleh dengan mengintegrasikan pendidikan agama dan pendidikan umum dalam satu kesatuan. Begitu juga Abdussyukur (2018) dalam kajiannya menemukan bahwa fondasi konsep pendidikan sekolah Islam terpadu adalah ideologi tarbiyah dengan paradigma integrasi keilmuan sehingga dapat dijadikan rujukan pengembangan pendidikan Islam masa depan. Dalam konteks kajian di Kalimantan Selatan terdapat beberapa kajian yang sudah dilakukan sebelumnya terkait sekolah Islam terpadu. Shafiyah (2007), Nawawi (2009), dan Halim (2010) menjadikan sekolah Islam terpadu sebagai objek material kajiannya. Hanya saja ketiga kajian tersebut lebih terfokus pada aspek teknik, pola, model pembelajaran, serta manajemen di sekolah Islam terpadu.

Kajian-kajian sebelumnya masih terbatas mengkaji sekolah Islam terpadu dan pemikiran Hasan Al-Banna secara terpisah. Penelusuran yang sudah dilakukan belum menemukan kajian yang secara spesifik menganalisis keterkaitan antara pemikiran Hasan AlBanna dengan praktik pendidikan di sekolah Islam terpadu. Oleh karena itu kajian ini bertujuan untuk mengisi kekosongan kajian tersebut dengan terfokus pada sekolah Islam terpadu Ukhuwah Banjarmasin.

Kajian ini bertujuan untuk meneroka praktik pendidikan di sekolah Islam terpadu Ukhuwah Banjarmasin yang mengindikasikan adanya relevansi antara program dan kegiatan pendidikan Islam di dalamnya dengan pemikiran pendidikan Islam Hasan Al-Banna. Hasil 
dari kajian ini akan mengemukakan keterkaitan sebuah lembaga pendidikan yang bertempat di kota Banjarmasin dengan suatu gerakan global yang dimotori oleh Ikhwanul Muslimin dengan pengaruh pemikiran Hasan Al-Banna. Kajian ini merupakan kajian literatur dan lapangan dengan mengambil sumber data penelitian ini dari observasi langsung, wawancara, dan studi lapangan. Kajian literatur dilakukan dengan penelusuran terhadap buku-buku, jurnal dan artikel-artikel internet. Kajian lapangan dilakukan di sekolah Islam terpadu Ukhuwah Banjarmasin dan tempat-tempat pertemuan dengan narasumber wawancara. Teknik pengambilan data di lapangan dilakukan dengan pengamatan, wawancara, dan dokumentasi. Analisa terhadap data-data yang ditemukan penulis lakukan dengan mendeskripsikan secara kritis keterkaitan antara pendidikan Islam di sekolah Islam terpadu Ukhuwah Banjarmasin dengan pemikiran pendidikan Hasan Al-Banna.

\section{HASIL DAN PEMBAHASAN \\ Pemikiran Pendidikan Hasan al-Banna}

Hasan Al-Banna (1906-1949) dikenal sebagai pendiri gerakan Ikhwanul Muslimin di Mesir. Sebagai pemimpin suatu gerakan ia lebih banyak menyampaikan pemikirannya lewat gerakan-gerakan praktis ketimbang karya tulis. Namun demikian, pemikirannya dapat diakses melalui beberapa karyanya, seperti Mudzakirat al-Da'wah wa al-Da'iyah dan Majmu'ah Rasa 'il, serta tulisan-tulisan para akademisi dan pengikut-pengikutnya yang jumlahnya sudah sangat banyak. Meskipun Al-Banna lebih banyak berbicara mengenai politik, tetapi Al-Banna juga memberikan sumbangan pemikiran dalam bidang pendidikan yang menjadi bagian dari gerakan politiknya. Karena itu, istilah tarbiyah dalam konteks Al-Banna dalam maknanya yang sedikit berbeda, yakni pembinaan dan kaderisasi. Pada tataran ini dapat dikatakan bahwa konsepsi pendidikan Hasan Al-Banna adalah proyek kaderisasi gerakan Ikhwanul Muslimin (Jung dan Zalaf 2020; Kramer 2009).

Pemikiran Hasan Al-Banna dalam bidang pendidikan tak lepas dari pengaruh situasi sosial-politik Mesir yang tampak di depan matanya ketika itu. Pasca kepemimpinan Sa'd Zaghlul, terjadi disintegrasi politik dalam negeri dan Mesir menjadi ajang pertarungan antar partai politik. Akibat pertarungan yang tidak sehat ini, memudarlah semangat nasionalisme yang berakibat kepada melemahnya bangsa Mesir. Selain itu, partai politik yang berkuasa ketika itu tidak lagi mengacu kepada nilai-nilai Islam dalam menentukan kebijaksanaan politiknya, tetapi sepenuhnya berkiblat kepada Barat. Seluruh aturan, kebiasaan, nilai-nilai moral, dan konsepsi politiknya berorientasi ke Barat. Dalam bidang agama dan moral, Mesir seakan sudah mengalami Westernisasi. Dominasi budaya Barat ini memicu kecenderungan orang-orang Mesir bergaya hidup Barat dan memungut gagasan-gagasan Barat (David 1995). Di bidang ekonomi, sumber daya alam, modal, serta pengawasan perekonomian berada di tangan Inggris yang mengakibatkan rakyat lemah dan jatuh miskin (David 1995). Di bidang politik, tampak adanya pengelompokan dan pemisahan yang tajam antara ahli politik dan ahli agama. Ahli agama dipandang hanya berwenang berbicara mengenai agama, dan ahli politik berwenang berbicara soal politik. Berbicara tentang politik dianggap tabu oleh ahli agama. Sebaliknya, lahir pula banyak partai yang mengaku tidak memiliki hubungan dengan soal agama (Dewan Redaksi Ensiklopedi Islam 1994).

Dalam bidang pendidikan pula terjadi kepincangan, terutama masalah kurikulum. Sekolah-sekolah pemerintah hanya mementingkan pengetahuan umum dan mengesampingkan ilmu-ilmu agama. Sebaliknya, sekolah-sekolah agama semata-mata mementingkan ilmu-ilmu agama dan tidak menghiraukan pengetahuan umum. Oleh karena itu, kurikulum pendidikan yang ada harus dirumuskan di atas pondasi ilmu-ilmu periferal an sich yang tidak memiliki banyak manfaat bagi kemajuan Mesir. Tujuan yang ingin dicapai dari kurikulum tersebut tidak lain hanya mencetak mesin-mesin tulis yang dapat menjalankan 
tugas-tugas pemerintahan. Dalam rangka menghapuskan identitas keberagamaan para siswa, pelajaran agama bukan lagi dijadikan sebagai mata pelajaran utama. Ia hanya merupakan mata pelajaran ekstra atau non-SKS yang tidak diujikan dan tidak memengaruhi lulus tidaknya seorang siswa. Demikian juga, pelajaran bahasa Inggris mengalahkan bahasa Arab (Al-Aziz dan Wibowo 2007).

Rentetan krisis itu sangat memprihatinkan Hasan Al-Banna. Menurutnya, kemerosotan yang tengah melanda Mesir itu hanya dapat diatasi dengan kembali kepada AlQur`an dan sunnah Nabi Muhammad SAW. Ide dasar yang dikemukakannya adalah Islam membawa ajaran yang sempurna, mencakup semua aspek kehidupan. Ide ini sesungguhnya merupakan antitesis terhadap ide sekularisme dan westernisme yang berkembang di kalangan masyarakat Mesir ketika itu, sekaligus mendorongnya untuk mendeklarasikan berdirinya Ikhwanul Muslimin pada Maret 1928. Tema-tema sentral yang menjadi kerangka pemikiran al-Ikhwân al-Muslimûn untuk melakukan gerakannya adalah berkaitan dengan masalah moral masyarakat, ekonomi, dan fungsionalisasi agama yang dinilai sudah kurang mampu membendung pengaruh sekularisme. Selain itu, dasar yang paling penting yang dijadikan doktrin Ikhwanul Muslimin dalam melancarkan pembaruannya, ada lima, yaitu Allah tujuan kami, Rasulullah teladan kami, Al-Qur`an undang-undang dasar hidup kami, Jihad adalah jalan perjuangan kami, dan Syahid di jalan Allâh adalah cita-cita luhur kami (Al-Banna 1992). Kelima doktrin itu selanjutnya digunakan sebagai dasar dalam perjuangan, baik dalam bidang politik, sosial, ekonomi, kebudayaan, maupun pendidikan.

Istilah tarbiyah dalam pemikiran Hasan Al-Banna lebih bermakna pembinaan dan kaderisasi ketimbang definisi pendidikan yang dikenal umumnya. Pembinaan dan kaderisasi yang dimaksud adalah bahwa pemikiran pendidikan Al-Banna sebenarnya merupakan bentuk pola pembinaan dan kaderisasi para dầi dan dâ'iyah yang mengemban misi menyampaikan ajaran Islam yang benar kepada seluruh umat. Dengan demikian pendidikan dalam pemikiran Hasan Al-Banna berorientasi pada dakwah (Al-Qardhawi 2005). Al-Banna juga menunjukkan posisi penting pemuda sebagai tulang punggung perkembangan umat. Generasi muda merupakan pendidik umat di masa depan, sehingga dakwah merupakan aktivitas penting yang dibebankan pada pemuda. Untuk itu, generasi muda harus disiapkan demi misi dakwah ini (Al-Banna 1992). Persiapan itu dilaksanakan dalam bentuk pembinaan dan kaderisasi.

Berdasarkan semangat tersebut Al-Banna menyatakan dengan jelas definisi pendidikan. Menurut Al-Banna pendidikan adalah cara ideal dalam berinteraksi dengan fitrah manusia, baik langsung (berupa kata-kata) maupun tidak langsung, berupa keteladanan, sesuai dengan sistem dan perangkatnya yang khas, untuk memproses perubahan diri manusia menuju kondisi yang lebih baik (Mahmud 2001). Butir penting yang dapat disorot dari definisi tersebut adalah mengenai sistem pendidikan. Mahmud (2001) menjelaskan bahwa yang dimaksud sistem dalam konsepsi tersebut adalah sistem yang disyariatkan Allah SWT dan dianjurkan kepada manusia agar menempuhnya.

Pendidikan dalam konsep Al-Banna memiliki dua pilar pokok. Pertama, pilar tarbawiy (pembinaan), terdiri atas pola belajar-mengajar dengan ragam perangkatnya yang bertujuan menyempurnakan potensi pribadi muslim yang terpelajar dan mengubahnya kepada kondisi yang lebih baik agar mampu berinteraksi dengan hidup dan kehidupan. Kedua, pilar tanzhimiy (institusional). Pilar ini terdiri atas dua jenis institusi yaitu internal dan eksternal. Institusi internal bertugas meletakkan aturan dan kode etik, disamping menetapkan batasan-batasan hubungan yang harus terjalin antara sesama muslim di setiap waktu dan tempat dalam naungan hak dan kewajiban. Institusi eksternal bertugas menetapkan batasanbatasan hubungan antara negara Islam dan lainnya, perihal aturan perang, damai, dakwah, 
kekuasaan, serta menjadikan Islam sebagai penutup bagi seluruh sistem nilai (Mahmud 2001).

Al-Banna memandang bahwa segala aspek kehidupan manusia berperan penting dalam proses pendidikan. Proses tersebut sejatinya memang dilaksanakan di sekolah dengan metode-metode yang tepat dan disiapkan. Meskipun demikian sistem-sistem kehidupan di luar sekolah juga perlu disusun, khususnya yang bersifat institusional (tan₹bimiy). Kondisi sosial dan negara bagi Al-Banna mempengaruhi proses pendidikan. Selain itu jika pendidikan bertujuan membentuk fitrah manusia kepada taqwa maka sistem yang baik adalah sistem Islam. Tidak heran jika Hasan Al-Banna bersama Ikhwanul Muslimin memperjuangkan negara Islam atau setidaknya negara berdasarkan Islam. Dengan demikian dapat dipahami bahwa esensi pendidikan Islam menurut Hasan Al-Banna adalah proses mempersiapkan peserta didik dengan persiapan yang menyentuh seluruh aspek kehidupannya, meliputi rohani, jasmani, dan akal-pikiran, begitu pula dengan kehidupan duniawi dan ukhrawinya. Proses tersebut dilengkapi dengan sistem pembinaan yang terpadu antara pendidikan di dalam lingkungan sekolah maupun dari luar sekolah. Oleh sebab itu, pendidikan mestinya bersifat integral dan komprehensif. Menurut Al-Banna, karakteristik inilah yang membedakan sistem Islam dengan sistem pendidikan lain. pada tataran ini sistem pendidikan Islam mencakup seluruh aspek kehidupan dengan cakupan yang terperinci dan detail (Mahmud 2001).

Dalam implementasi pemikiran pendidikan Hasan Al-Banna, gerakan Ikhwanul Muslimin mengenalkan konsep Usrah. Konsep ini memandang bahwa pendidikan Islam perlu didasarkan pada rasa persaudaraan yang kokoh, keterpautan, dan kepedulian dengan sesama anggota, bahkan kalau perlu siap menghadapi penderitaan. Al-Banna (1992) menyatakan bahwa Usrah memiliki tiga pilar. Pertama, saling kenal (ta'aruf) yang akan menjamin persatuan. Kedua, sesama anggota harus saling memahami (tafahum) satu sama lain dengan saling menasihati. Ketiga, sesama anggota harus saling memperlihatkan solidaritas dengan saling membantu (takaful). Lebih lanjut tentang usrah, Al-Banna menuturkan:

"Islam sangat menganjurkan agar pemeluknya membentuk kumpulan-kumpulan keluarga dengan tujuan mengarahkan mereka untuk mencapai tingkat keteladanan, mengokohkan persatuan, dan mengangkat konsep persaudaraan di antara mereka dari tataran kata-kata dan teori menuju kerja dan operasional yang konkret. Oleh karena itu, bersungguh-sungguhlah engkau wahai saudaraku untuk menjadi batu-bata yang baik dalam bangunan Islam" (Al-Banna 1992).

Demi menguatkan nilai-nilai tersebut, anggota Ikhwanul Muslimin mengadakan pertemuan mingguan yang didalamnya mereka saling menyampaikan problem sehari-hari dan saling membantu memecahkannya. Pada pertemuan ini, para anggota juga membahas persoalan-persoalan keislaman dan studi buku-buku (David 1995). Pertemuan semacam ini kemudian diimplementasikan dalam pendidikan sekolah Islam terpadu dengan nama program mentoring.

Hasan Al-Banna melalui Ikhwanul Muslimin membangun dan menjalankan lembaga pendidikan formal dan non-formal (luar sekolah). Ikhwanul Muslimin membentuk komite khusus di bidang pendidikan di kantor pusat yang bertugas mendirikan sekolah dasar, sekolah lanjutan, dan sekolah teknik untuk anak laki-laki dan perempuan yang keadaannya berbeda dengan sekolah-sekolah swasta lainnya. Menshawy (2020) menyebutkan bahwa Ikhwanul Muslimin memberikan ciri Islam yang sangat kuat ke dalam seluruh jenjang pendidikan formal tersebut.

Berkenaan dengan pendidikan non formal, Al-Banna berpandangan bahwa pendidikan tersebut diselenggarakan di luar sekolah melalui kegiatan belajar-mengajar yang berkesinambungan dan tidak harus berjenjang. Pendidikan non formal dapat dilaksanakan 
melalui keluarga, kelompok belajar, kursus, dan satuan pendidikan lain yang sejenis. Realisasinya Ikhwanul Muslimin menyelenggarakan pendidikan keagamaan, kursus, kejuruan untuk anak putus sekolah, pendidikan khusus bagi anak laki-laki dan perempuan, serta pendidikan kewiraswastaan bagi mereka yang tidak mampu lagi untuk meneruskan sekolah ke jenjang yang lebih tinggi. Untuk masyarakat luas, Ikhwanul Muslimin juga menyelenggarakan pendidikan dengan sistem halaqah, yaitu pendidikan yang diselenggarakan secara berkelompok dan membentuk lingkaran yang dibimbing oleh guru yang disebut naqib (Willi 2020). Pendidikan dengan model ini juga erat kaitannya dengan sistem dakwah Usrah. Keterlibatan anggota Ikhwanul Muslimin dalam halaqah usrah merupakan suatu kewajiban karena ia adalah unsur pokok dalam pergerakan serta sebagai fondasi pergerakan. Selain halaqah, Ikhwanul Muslimin juga menyelenggarakan beberapa program pendidikan yang lain yaitu katibah (tarbiyah ruhani), riblah (studi wisata), mukhayyam (perkemahan), mu'askar (outbond semi-militer), daurah (pelatihan), nadwah (kajian ilmiah dari para pakar atau spesialis), dan muktamar (Mahmud 2001).

\section{Profil Sekolah Islam Terpadu Ukhuwah Banjarmasin: dari Gerakan Sosial hingga hubungan Ideologis dengan Partai Keadilan Sejahtera}

Gerakan sosial seringkali dilatarbelakangi oleh ketidakadilan dan keinginan atas perubahan ke arah lebih baik. Gerakan sosial lahir dari masyarakat yang menuntut perubahan dalam institusi, kebijakan atau struktur pemerintahan. Namun gerakan sosial itu tidak dapat lahir tanpa kondisi yang mendukung dan memberikan ruang bagi gerakan tersebut. Selanjutnya, gerakan sosial ini merupakan gelombang pergerakan dari individu-individu menjadi kelompok yang mempunyai tujuan yang sama yaitu suatu perubahan sosial (Situmorang 2007). Dalam konteks ini gerakan sosial yang diusung Hasan Al-Banna melalui Ikhwanul Muslimin adalah respon terhadap krisis yang terjadi dalam masyarakat. Pada tataran ini kehadiran sekolah Islam terpadu merupakan sebuah gerakan sosial oleh masyarakat yang menginginkan perubahan dalam pendidikan Islam.

Data yang diperoleh melalui wawancara yang dilakukan terhadap pimpinan yayasan Ukhuwah menunjukkan bahwa pendirian sekolah Islam terpadu Ukhuwah juga dilatarbelakangi oleh ketidakpuasan para pendiri terhadap kondisi pendidikan Islam dan lembaga-lembaga pendidikan Islam di Indonesia. Ketidakpuasan tersebut kemudian melatarbelakangi inisiatif mendirikan sekolah Islam yang sesuai dengan keinginan dan harapan. Ketidakpuasan itu terlihat jelas pula dalam pernyataan Fahmy Alaydroes bahwa pendidikan Islam telah mengalami krisis dalam berbagai dimensi (eramuslim.com 2010). Pada kesempatan lain Fahmi Alaydroes juga menyatakan kondisi memperihatinkan tersebut menimbulkan inisiatif untuk melakukan gerakan pembaharuan pendidikan yang diwujudkan dalam bentuk sekolah Islam terpadu (Tim Penyusun JSIT 2006).

Sejarah sekolah Islam terpadu Ukhuwah Banjarmasin secara khusus tidak terlepas dari peran para pendiri yang terdiri atas Muhammad Ihsanuddin, Sri Adi Nugroho, dan Istiadi Heri Wioko. Muhammad Ihsanuddin adalah anggota legislatif DPRD Kalimantan Selatan Fraksi Partai Keadilan Sejahtera (PKS). Gagasan pendirian sekolah Islam terpadu dari ketiga pendiri tersebut dilaterbelakangi ketika akan memasukkan anak-anaknya ke sekolah. Mereka melihat keadaan pendidikan di Indonesia yang tidak memuaskan ideologi yang mereka pegang hingga kemudian memutuskan untuk mendirikan sebuah lembaga pendidikan yang dapat mengayomi anak didik secara menyeluruh dan terpadu. Mengawali upaya tersebut, mereka kemudian mendirikan sebuah yayasan yang diberi nama Yayasan Ukhuwah yang sebelumnya sah secara hukum Negara pada tahun 1993. Di tahun yang sama, berdiri Sekolah Dasar Islam Terpadu Nurul Fikri di Depok, yang kemudian menjadi kiblat dan sumber rujukan pengurus Yayasan Ukhuwah dalam mempelajari gagasan dan konsep 
sekolah Islam terpadu Ukhuwah. Enam tahun kemudian, baru lembaga pendidikan Ukhuwah pertama berdiri yaitu taman kanak-kanak Islam Terpadu (TKIT) pada tahun 1999.

Pada Awal beroperasi TK Islam terpadu Ukhuwah meminjam bangunan bekas SMA Kebun Bunga di Jalan Dahlia, Kebun Bunga, Banjarmasin. Kemudian pada tahun 2001 berdiri sekolah dasar Islam terpadu Ukhuwah yang pada awalnya juga meminjam bangunan milik Yayasan Al-Muddakir di Banua Anyar Banjarmasin. Baru pada tahun 2005 seluruh lembaga di bawah naungan Yayasan Ukhuwah menyatu dan berpindah ke komplek Handayani, Jalan Bumi Mas Raya, Banjarmasin. Dalam perkembangan selanjutnya berdirilah lembaga-lembaga pendidikan Islam terpadu Ukhuwah lain, yaitu kelompok bermain Islam terpadu (KBIT) Ukhuwah tahun 2003, tempat penitipan anak Islam terpadu Ukhuwah tahun 2004, sekolah menengah pertama Islam terpadu Ukhuwah tahun, dan Madrasah Tahfizh AlQur'an tahun 2011.

Kemudian pada tahun 2013 yayasan Ukhuwah dikelola dengan struktur kepengurusan berikut:

Tabel 1. susunan pengurus Yayasan Ukhuwah, Banjarmasin

\begin{tabular}{lll}
\hline \multicolumn{1}{c}{ Jabatan } & \multicolumn{1}{c}{ Nama Pengurus } \\
\hline Dewan Pendiri & - & Muhammad Ihsanuddin \\
& - & Sri Adi Nugroho \\
Dewan Pembina & - & Istiadi Heri Wiwoko \\
& - & H. Riswandi, SIP (ketua) \\
& - & H. Riyadi, SE (anggota) \\
Dewan Pengawas & - & Ibnu Sina, S.Pi, M.Si (ketua) \\
& - & Akhmad Jazuli, S.Ked, MAP (anggota) \\
Dewan Penasihat & - & H. Khairullah, ST (anggota) \\
& - H. Abdullah Riadi \\
& - Daini Dahlan \\
Ketua Yayasan & - H. Anwar Luthfi Haini HA, M.Pd.I \\
Sekretaris Yayasan & H. Haryanto, SE \\
Bendahara Yayasan & Khairani, S.Pd.I \\
Sumber: hasil pengumpulan data Hasan, SE
\end{tabular}

Data yang diperoleh dari informan menunjukkan bahwa pengurus yayasan Ukhuwah dan guru-guru sekolah Islam terpadu Ukhuwah memiliki keterkaitan dengan Partai Keadilan Sejahtera (PKS). Keterkaitan tersebut baik sebagai kader partai maupun sebagai simpatisan partai. Temuan tersebut sejalan dengan pandangan Noorhaidi Hasan (dalam Yusup 2017) bahwa jaringan sekolah Islam terpadu (JSIT) didirikan dan berafiliasi secara politis kepada Partai Keadilan Sejahtera (PKS). Melalui jaringan sekolah Islam terpadu (JSIT), Partai Keadilan Sejahtera tidak hanya memperkenalkan modernisasi manajemen kelembagaan tetapi juga menanamkan ideologi Islam yang sejalan dengan pandangan Partai Keadilan Sejahtera dalam lembaga pendidikan tersebut. Noorhaidi Hasan (2012) juga menyebutkan bahwa jaringan sekolah Islam terpadu (JSIT) tampaknya diharapkan menjadi media perekrutan kader-kader Partai Keadilan Sejahtera sekaligus sarana memperluas basis dukungan.

Pandangan terkait hubungan yang bersifat struktural dengan PKS dan sebagai sekolah calon kader PKS disanggah oleh sekolah Islam terpadu Ukhuwah. Setidaknya ada dua argumen sanggahan yang disampaikan. Pertama, secara historis sekolah Islam terpadu pertama yaitu SDIT Nurul Fikri Depok lebih dahulu berdiri yaitu tahun 1993 dibandingkan 
Partai Keadilan Sejahtera pada tahun 1998. Kedua, dalam Anggaran Rumah Tangga (ART) JSIT. Pasal 5, 6, dan 7 pada ART tersebut mengatur mengenai persyaratan anggota, prosedur penerimaan anggota, dan hak dan Kewajiban Anggota. Pasal-pasal ini menandakan bahwa sekolah-sekolah yang berada di bawah naungan JSIT tidak mesti berasal dari pihak-pihak yang bergelut dalam politik PKS selama sekolah-sekolah tersebut menganut dan melaksanakan prinsip dan konsep dasar SIT yang telah baku. Konsep SIT baku tersebut tertuang sepenuhnya dalam 2 buku yang disusun oleh tim penyusun JSIT dan menjadi panduan pelaksanaan SIT, yakni Sekolah Islam Terpadu, Konsep dan Aplikasinya, (2006) dan Standar Mutu Sekolah Islam Terpadu (2010).

Meskipun demikian, sanggahan tersebut tidak serta merta menutupi realitas bahwa pengurus yayasan dan guru-guru sekolah Islam terpadu Ukhuwah adalah kader atau simpatisan Partai Keadilan Sejahtera (PKS). Data yang diperoleh dari Hendra yang merupakan ketua DPW PKS Kalimantan Selatan Bidang Hubungan Masyarakat menegaskan realitas tersebut. Hendra menyatakan bahwa hubungan antara sekolah Islam terpadu dan Partai Keadilan Sejahtera adalah hubungan kultural. Dalam hubungan tersebut kader-kader PKS memiliki pemikiran untuk membangun pola dan lembaga pendidikan yang sesuai dengan yang diinginkan. Bejo Riyanto yang menjabat sebagai direktur pendidikan sekolah Islam Terpadu Ukhuwah juga memandang bahwa hubungan sekolah Islam terpadu dengan PKS adalah hubungan ideologis, yaitu visi-misi dan kerangka pemikiran yang sama. Selain itu Ibnu Sina yang menjabat sebagai ketua umum DPW PKS Kalimantan Selatan juga menyatakan bahwa hubungan sekolah Islam terpadu dengan PKS tidak hanya hubungan yang bersifat ideologis, tetapi juga emosional, seperti halnya Muhammadiyah dengan Partai Amanat Nasional (PAN) atau Nahdhatul Ulama (NU) dengan Partai Kebangkitan Bangsa. Keterangan dari infiorman penelitian tersebut menunjukkan bahwa pada tataran struktural memang tidak ada hubungan antara sekolah Islam terpadu dengan Partai Keadilan Sejahtera (PKS), namun hubungan kedua lembaga tersebut lebih kepada hubungan ideologis. Temuan tersebut sejalan dengan pandangan Noorhaidi Hasan (2012) bahwa meskipun tidak memiliki afiliasi formal maupun struktural antara jaringan sekolah Islam terpadu (JSIT) dengan Partai Keadilan Sejahtera, namun jaringan sekolah Islam terpadu (JSIT) seringkali dikenal sebagai jaringan sekolah bentukan kader-kader PKS.

\section{Pendidikan Islam di Sekolah Islam Terpadu Ukhuwah Banjarmasin}

Kata kunci dalam memahami landasan dasar pendidikan di sekolah Islam terpadu Ukhuwah Banjarmasin dan menjadi elemen pembedanya dengan sekolah lain adalah esensi pada istilah terpadu. Penggunaan istilah tersebut dimaksudkan sebagai penguat (tankî́d) dari Islam itu sendiri yaitu Islam yang menyeluruh, integral, bukan parsial. Inilah yang menjadi semangat utama dalam gerak dakwah di bidang pendidikan sebagai perlawanan terhadap pemahaman yang sekuler dan dikotomis (Tim Penyusun JSIT 2006).

Istilah terpadu dalam nama sekolah Islam terpadu mencakup empat dimensi. Pertama, keterpaduan ontologi pendidikan, yaitu tidak ada dikotomi parsial antara ilmu agama dan ilmu umum. Kedua, keterpaduan obyek pendidikan, yaitu manusia dengan segala dimensinya. Ketiga, keterpaduan metode pembelajaran. Keempat, keterpaduan subjek pendidikan, yaitu tanggung jawab pendidikan tak hanya diemban sekolah, melainkan juga melibatkan masyarakat dan keluarga. Empat dimensi keterpaduan tersebut tercakup dalam definisi pendidikan Islam dalam perspektif sekolah Islam terpadu yaitu suatu proses membina seluruh potensi manusia sebagai makhluk yang beriman dan bertaqwa, berfikir, dan berkarya, sehat, kuat, dan berketerampilan tinggi untuk kemaslahatan diri dan lingkungannya (Tim Penyusun JSIT 2006). 
Data yang diperoleh menunjukkan bahwa sekolah Islam terpadu Ukhuwah Banjarmasin mengintegrasikan nilai Islam ke dalam bangunan kurikulum. Prinsip ini diaktualisasikan dengan cara memasukkan nilai-nilai Islam ke dalam pelajaran-pelajaran seperti ilmu pengetahuan alam, ilmu pengetahuan sosial, dan seni. Sistem mengajar seperti ini didasarkan pada prinsip rabbaniyah (Tim Penyusun JSIT 2006). Sekolah Islam terpadu Ukhuwah juga menerapkan dan mengembangkan metode pembelajaran. Diantara bentuk pengembangan metode pembelajaran adalah metode curah gagasan (brainstorming), metode kelompok sibuk (buzz group), dan metode studi kasus (case study) (Tim Penyusun JSIT 2006). Dengan metode-metode tersebut siswa dipicu daya kritis dan kepeduliannya terhadap masalah sosial di sekitarnya.

Sekolah Islam terpadu Ukhuwah Banjarmasin mengedepankan qudwah hasanah atau keteladanan dalam membentuk karakter peserta didik. Guru diwajibkan memiliki kompetensi kepribadian yang telah ditetapkan yaitu akidah yang lurus, ibadah yang benar, akhlak yang mulia, sehat dan bugar, rapi, bersih, tertib, dan cermat, menghargai waktu, arif dan bijaksana, terbuka dan mudah bekerjasama (Tim Penyusun JSIT 2006). Menurut Bejo Riyanto, guru bahkan tidak diperkenankan untuk terlalu lama berada di dalam ruang guru, tetapi selalu berinteraksi dan bergaul dengan para siswa bahkan pada saat waktu istirahat. Orang tua juga berperan penting dalam strategi ini. Pihak sekolah Islam terpadu Ukhuwah selalu berkomunikasi dengan orang tua perihal peran orang tua memberikan qudwah hasanah di rumah.

Sekolah Islam terpadu Ukhuwah berupaya menumbuhkan bi'ah shalibah (lingkungan saleh) dalam iklim dan lingkungan sekolah. Nilai yang terkandung dalam penataan lingkungan ini adalah dengan menumbuhkan kemaslahatan dan meniadakan kemungkaran (Tim Penyusun JSIT 2006). Untuk tujuan yang bersifat pembinaan akhlak dan kepribadian siswa ini, sekolah Islam terpadu Ukhuwah melaksanakan beberapa program. Pertama, program mentoring (halaqah) yaitu program pembinaan berkelompok dengan 3 hingga 12 orang siswa setiap kelompok. Dalam program ini setiap kelompok didampingi mentor yang berasal dari guru, orang tua, ataupun mentor dari luar sekolah yang memenuhi kualifikasi sebagai mentor. Mentor disebut dengan Naqib yaitu istilah yang juga digunakan untuk menunjuk guru dalam halaqah usrah Ikhwanul Muslimin. Pada program sekolah Islam terpadu berkesempatan untuk lebih fokus bergerak di bidang dakwah. Hal ini karena program ini bersifat terbuka bagi pihak-pihak luar sekolah, khususnya aktivis dakwah yang ditunjuk oleh sekolah untuk masuk ke dalam pendidikan sekolah Islam terpadu Ukhuwah.

Program mentoring berisikan pemberian materi-materi keislaman, seperti akidah, fiqih, sejarah Islam dengan tujuan pencapaian kompetensi-kompetensi kurikulum akhlak. Selain pemberian materi, program ini juga bagian dari upaya penumbuhan semangat persaudaraan seperti dalam program halaqah usrah. Bejo Riyanto menyatakan bahwa program ini baru dilaksanakan pada tingkat sekolah menenga pertama (SMP).

Kedua, program malam bina iman dan taqwa(mabit). Program ini biasanya dilakukan sekali dalam setiap bulan bulan Qamariyyah atau malam bulan purnama. Pelaksanaan program ini adalah dengan bermalam bersama antara siswa-siswa dengan pembimbingnya di suatu tempat. Program ini berisi rangkaian kegiatan seperti mendengarkan ceramah agama, menonton film Islami edukatif, membaca atau mendengarkan bacaan Al-Qur'an, bangun malam untuk ibadah malam (qiyam al-lail), sahur bersama untuk bekal puasa sunnat keesokan harinya dan diakhiri dengan shalat subuh berjamaah, zikir, dan doa bersama. Tujuannya lebih ditekankan pada upaya melatih siswa untuk meningkatkan kualitas hubungan dengan Allâh SWT (Tim Penyusun JSIT 2006). Bejo Riyanto menyebutkan bahwa di dalam kegiatan ini diajarkan doa-doa dan dzikir Hasan Al-Banna dari karyanya yaitu Al-Ma'tsurat. 
Selain kedua program tersebut sekolah Islam terpadu Ukhuwah Banjarmasin juga melaksanakan program-program lain, seperti Pandu SIT (semacam kegiatan kepramukaan), kelompok ilmiah remaja, bulan sabit merah remaja, studi wisata (riblab), Mu'askar (outbond), achievement motivation training (AMT) dan berbagai lomba-lomba (Tim Penyusun JSIT 2006). Program dan kegiatan tersebut baik metode maupun teknisnya terinspirasi dari programprogram pendidikan Usrah Ikhwanul Muslimin. Sekolah Islam terpadu Ukhuwah juga melibatkan peran serta orang tua dan masyarakat dalam pendidikan. Untuk mewujudkan peran serta tersebut, dibentuk komite sekolah yang berisi para orang tua dan masyarakat yang berperan sebagai pemberi pertimbangan dalam penentuan dan pelaksanaan kebijakan pendidikan. Komite sekolah beranggotakan perwakilan orang tua dan wali siswa, tokoh masyarakat atau pakar pendidikan yang disepakati, dunia usaha dan industri, perwakilan forum alumni, perwakilan siswa minimal jenjang SMA, organisasi profesi, dan dewan guru. Anggota masyarakat sekitar sekolah juga dilibatkan dalam komite (Tim Penyusun JSIT 2006). Keberadaan komite sekolah secara tidak langsung dapat berfungsi sebagai media dakwah pihak sekolah Islam terpadu terhadap masyarakat, sebab dalam hampir setiap pertemuannya diselingi dengan ceramah atau orasi keagamaan.

\section{Relevansi Pendidikan Sekolah Islam Terpadu Ukhuwah dengan Pemikiran Pendidikan Hasan Al-Banna}

Pelaksanaan pendidikan di sekolah Islam terpadu Ukhuwah Banjarmasin memiliki relevansi dengan pemikiran pendidikan Hasan Al-Banna yang juga terimplementasi dalam pola pembinaan kader Ikhwanul Muslimin. Relevansi tersebut dapat dilihat dalam dua dimensi, yaitu relevansi ideologis dan relevansi aplikatif.

\section{Relevansi Ideologis}

Relevansi ideologis menekankan adanya arus ide yang mengalir dari pemikiran pendidikan Hasan Al-Banna kepada sekolah Islam terpadu Ukhuwah Banjarmasin. Relevansi ideologis juga menjelaskan hubungan antara Ikhwanul Muslimin dengan Islam di Indonesia. Relevansi ideologis ini terlihat dari hubungan ideologis antara sekolah Islam terpadu dengan kader Partai Keadilan Sejahtera. Pada tataran ini Partai Keadilan Sejahtera sangat dipengaruhi oleh ideologi Ikhwanul Muslimin yang didirikan oleh Hasan Al-Banna. Pengaruh tersebut dikonfirmasi dengan pengumpulan data melalui wawancara dengan pimpinan Partai Keadilan Sejahtera Kalimantan Selatan dan direktur pendidikan sekolah Islam terpadu Ukhuwah Banjarmasin. Ibnu Sina yang merupakan ketua umum DPW PKS Kalimantan Selatan menyebutkan bahwa PKS mendapatkan inspirasi dan rujukan pemikiran dari Ikhwanul Muslimin. Bahkan, kader-kader PKS diwajibkan untuk membaca buku-buku karya Hasan Al-Banna. Pandangan tersebut diperkuat dengan pernyataan Hendra yang merupakan Ketua DPW PKS Kalimantan Selatan Bidang Hubungan Masyarakat, bahwa Hasan AlBanna dengan Ikhwanul Muslimin telah memberikan pencerahan dan inspirasi terbaik dalam memperbaiki dan membangun peradaban Islam. Selain itu Bejo Riyanto yang merupakan direktur pendidikan sekolah Islam terpadu Ukhuwah mengakui bahwa sekolah Islam terpadu Ukhuwah mengambil rujukan konsepsi dan semangat pendidikan pemikiran Hasan Al-Banna sambil memadukannya dengan pemikiran pendidikan Barat yang dianggap tidak mengganggu nilai-nilai Islam.

\section{Relevansi Aplikatif}

Relevansi aplikatif dapat dimaknai dengan upaya sekolah Islam terpadu Ukhuwah Banjarmasin menterjemahkan pemikiran Hasan Al-Banna dalam praktik dan pola pendidikan. Relevansi aplikatif yang paling kontras dalam praktik pendidikan sekolah Islam terpadu Ukhuwah Banjarmasin adalah integralisasi ilmu agama dan non-agama. Integralisasi 
ilmu merupakan tema penting yang memenuhi atmosfer revivalisme Hasan Al-Banna pada awal abad ke-20, seiring dengan munculnya kesadaran akan pentingnya ilmu-ilmu nonkeagamaan bagi peradaban Islam. Namun ilmu-ilmu yang disadari sebagai warisan peradaban Islam dinilai telah kehilangan aspek spiritualnya sehingga digunakan untuk tujuan yang tidak berlandaskan pada nilai-nilai keluhuran. Oleh karena itu dalam pandangan revivalis, ilmu-ilmu dari Barat yang sekuler itu harus disucikan terlebih dahulu dan memberinya nilai-nilai ketuhanan (Bakir 2018; Fahrudin, Mulyadi, dan Ichsan 2020). Berbagai upaya dilakukan oleh para cendekiawan Islam untuk tujuan tersebut, termasuk upaya yang dilaksanakan Hasan AlBanna dalam rangka dakwah tarbiyah Ikhwanul Muslimin. Sebagai tokoh yang hidup di masa revivalisme Islam dan dipengaruhi oleh pemikiran-pemikiran pembaharu, Al-Banna memperkenalkan pendidikan berdasarkan integralisme ilmu.

Integralisme ilmu dan pendidikan dalam perspektif Al-Banna didasarkan pada kesadaran akan potensi manusia yang integral. Oleh sebab itu, definisi pendidikan bagi Hasan Al-Banna adalah cara ideal dalam berinteraksi dengan fitrah manusia. Proses interaksi tersebut dilaksanakan dalam metode yang integral pula, baik metode yang dilaksanakan di dalam kelas maupun metode yang dilaksanakan di luar sekolah (Jannah 2017). Prinsip integralisme ilmu ini kemudian diaplikasikan dalam pendidikan sekolah Islam terpadu Ukhuwah Banjarmasin. Dengan prinsip integralisme ilmu Hasan Al-Banna, sekolah Islam terpadu Ukhuwah berupaya memadukan seluruh aspek manusia sebagai objek pendidikan dan seluruh jenis ilmu sebagai subjek pendidikannya.

Aspek rubaniyah dalam pemikiran pendidikan Hasan Al-Banna diimplementasikan dalam bentuk kurikulum Pendidikan Agama Islam (PAI) dan pendidikan Al-Qur'an. Aspek intelektual dilaksanakan dalam bentuk kurikulum Nasional yang memuat segala ilmu umum. Adapun aspek jasmani dilaksanakan dalam bentuk seperti kurikulum kepanduan dan kurikulum keterampilan. Pendidikan rubaniyyah kemudian menjadi pokok orientasi dalam bentuk pendidikan akhlak, pendidikan sosial, dan bahkan politik. Pendidikan akhlak diaktualisasikan dalam bentuk pemberlakuan tata tertib sekolah yang beorientasi adab dan sopan santun, pelaksanaan program-program pembinaan kesiswaan berupa mentoring (balaqah), pengisian lembar muhasabah, dan malam bina iman dan taqwa (mabit). Pembinaan akhlak juga disajikan bagi murid dalam bentuk keteladanan para guru dan karyawan sekolah.

Adapun pendidikan sosial dilakukan dalam berbagai bentuk kegiatan. Diantara kegiatan tersebut seperti Pandu SIT untuk membina jiwa kepemimpinan anak didik, kegiatan bulan sabit merah remaja dalam membina jiwa kepedulian terhadap sesama, riblah, kunjungan ke panti-panti asuhan. Diantara kegiatan pembinaan kesiswaan yang menjadi ciri khas sekolah Islam terpadu Ukhuwah adalah mentoring atau halaqah. Aktivitas halaqah ini adalah aktualisasi dakwah gerakan tarbiyah yang terinspirasi dari metode dakwah Usrah Ikhwanul Muslimin kemudian disesuaikan dengan konteks pendidikan dasar dan menengah.

Kegiatan usrah merupakan program kaderisasi paling esensial dalam Ikhwanul Muslimin. Hal ini karena di dalamnya berisi unsur pokok dalam pergerakan serta sebagai fondasi awal dalam struktur bangunan jamaah ke dalam jiwa setiap anggota. Pilar usrah adalah harus saling kenal (ta'aruf), saling memahami (tafabum), dan saling bersolidaritas (takaful) dengan saling membantu. Dalam konteks sekolah Islam terpadu Ukhuwah Banjarmasin, usrah dapat ditemukan pada setiap unsur sekolah, mulai dari kepala sekolah, guru, hingga orang tua siswa yang dilibatkan dalam proses pendidikan. Kepala sekolah, guru dan karyawan sekolah dipertemukan dalam berbagai forum dan perkumpulan keakraban, seperti liqa, siswa diberikan kegiatan-kegiatan yang menanamkan sifat persaudaraan, seperti lomba-lomba, perkemahan.

Hubungan antara pemikiran Hasan Al-Banna dengan sekolah Islam terpadu Ukhuwah Banjarmasin tidak hanya pada tataran praktik pendidikan kurikuler dan 
ekstrakulikuler. Pada tataran ini guru, karyawan, dan siswa sekolah Islam terpadu diajarkan dan dianjurkan untuk mempraktekkan wirid, doa dan zikir Hasan Al-Banna dalam karyanya yaitu Al-Ma'tsurat. Realitas ini menunjukkan hubungan aplikatif antara pemikiran Hasan AlBanna dengan sekolah Islam terpadu Ukhuwah juga dalam ritualitas personal setiap orang yang memiliki keterkaitan dengan sekolah Islam terpadu Ukhuwah Banjarmasin.

\section{PENUTUP}

Kajian ini menemukan bahwa pengaruh ideologi keagamaan Ikhwanul Muslimin terlihat begitu jelas dalam praktik pendidikan maupun dalam ideologi sekolah Islam terpadu Ukhuwah Banjarmasin. Pengaruh tersebut tidak mengherankan mengingat latar belakang historis berdirinya sekolah Islam terpadu Ukhuwah memiliki keterkaitan dengan pemikiran pendiri Ikhwanul Muslimin yaitu Hasan Al-Banna. Terlebih lagi tokoh pendiri, pengurus, guru, dan karyawan di sekolah Islam terpadu Ukhuwah Banjarmasin memiliki keterkaitan dengan Partai Keadilan Sejahtera baik sebagai kader maupun simpatisan yang juga dipengaruhi oleh pemikiran politik Ikhwanul Muslimin. Pada tataran ini meskipun tidak ada kaitan secara struktural antara Ikhwanul Muslimin, Partai Keadilan Sejahtera (PKS), dan sekolah Islam terpadu Ukhuwah Banjarmasin, namun ketiga lembaga ini memiliki hubungan emosional dan ideologis. Kajian ini juga menemukan bahwa relevansi pemikiran Hasan AlBanna praktik pendidikan Islam di sekolah Islam terpadu Ukhuwah Banjarmasin memiliki relevansi ideologis dan aplikatif dengan pemikiran pendidikan Hasan Al-Banna. Pada tataran ideologis, pemikiran Hasan Al-Banna menjadi fondasi ideologi pendidikan di sekolah Islam terpadu Ukhuwah Banjarmasin. Pemikiran Hasan Al-Banna dalam konteks ideologis dijadikan sebagai ruh dari setiap kebijakan dan program pendidikan sekolah Islam terpadu Ukhuwah Banjarmasin. Sedangkan pada tataran aplikatif, pemikiran Hasan Al-Banna di implementasikan dalam praktik pendidikan dan kurikulum yang digunakan di sekolah Islam terpadu Ukhuwah Banjarmasin. Dalam konteks ini pola pendidikan di sekolah Islam terpadu Ukhuwah berupaya mengintegrasikan antara ilmu agama dan non-agama dalam setiap program pendidikannya. Integrasi ini kemudian menjadi ciri khas sekolah Islam terpadu Ukhuwah dibandingkan dengan sekolah lain yang ada di Banjarmasin. Secara spesifik inspirasi praktik pendidikan di sekolah Islam terpadu Ukhuwah Banjarmasin bersumber dari gerakan tarbiyah Ikhwanul Muslimin. Berdasarkan temuan tersebut dapat disimpulkan bahwa pendidikan Islam di sekolah Islam terpadu Ukhuwah tidak sekadar menjadikan ideologi keagamaan Hasan Al-Banna sebagai fondasi pendidikan, namun juga merupakan aktualisasi gerakan tarbiyah Ikhwanul Muslimin dan media aktualisasi pendidikan bagi kader Partai Keadilan Sejahtera. 


\section{DAFTAR PUSTAKA}

Abdussyukur, Abdussyukur. 2018. "Konsep Dan Praktik Sekolah Islam Terpadu Dan Implikasinya Dalam Pengembangan Pendidikan Islam Di Indonesia." Disertasi, Surabaya: Universitas Islam Negeri Sunan Ampel. http://digilib.uinsby.ac.id/32045/.

Al-Aziz, Jum'ah Amin Abd, dan Syafrudin Edi Wibowo. 2007. Binâ Dâkbiliy 1928--1938: Sejarah Pembentukan dan Perkembangan Jama'ah Al-Ikhwân al-Muslimûn. Solo: Era Intermedia.

Al-Banna, Hasan. 1992. Majmû̉ ab Rasầil al-Imam al-Syabid Hasan al-Bannâ.

Al-Qardhawi, Yusuf. 2005. Tarbiyah Hasan Al-Bannầ dalam Jamẩah Al-Ikhwân al-Muslimûn. Diterjemahkan oleh Asep Sobari. Jakarta: Robbani Press.

Apple, Michael. W. 2019. Ideology and Curriculum. Fourth Edition. New York: Routledge.

Bakir, M. 2018. "Menelusuri Sekularisme Dalam Konteks Keberagamaan." AT-TURAS: Jurnal Studi Keislaman 5 (1): 82-96. https://doi.org/10.33650/at-turas.v5i1.325.

Bubalo, Anthony, Greg Fealy, dan Whit Mason. 2008. Zealous Democrats: Islamism and Democracy in Egypt, Indonesia and Turkey. New South Wales: Lowy Institute for International Policy.

David, Commins. 1995. Hasan Al-Banna, dalam Ali Rabnema (ed.), Para Perintis Zaman Baru Islam. Diterjemahkan oleh Ilyas Hasan. Bandung: Mizan.

Dewan Redaksi Ensiklopedi Islam. 1994. Ensiklopedi Islam Jilid I. Jakarta: Ichtiar Baru Van Hoeve.

Djalaluddin, Muhammad Mawardi. 2015. "Pemikiran Pendidikan Islam Hasan Al-Banna." Shaut al Arabiyyah 4 (1): 61-70. https://doi.org/10.24252/saa.v4i1.1063.

eramuslim.com. 2010. "Habib Fahmi Alaydrus: Soal Pendidikan, Indonesia Masih Latah!" Eramuslim. 2010. https://www.eramuslim.com/berita/bincang/habib-fahmialaydrus-soal-pendidikan-indonesia-masih-latah.htm.

Fahrudin, Henki Desri Mulyadi, dan Ahmad Shofiyuddin Ichsan. 2020. "Islamisasi Ilmu sebagai Identitas Keagamaan (Telaah Kritis Syed Naquib Al-Attas)." Alfuad: Jurnal Sosial Keagamaan 4 (1): 67-79. https://doi.org/10.31958/jsk.v4i1.2099.

Hadiz, Vedi. R. 2016. Islamic Populism in Indonesia and the Middle East. Cambridge: Cambridge University Press.

Halim, Abdul. 2010. "Sistem Boarding School dalam Pembinaan Akhlak Siswa pada Sekolah Menengah Atas Islam Terpadu Qardhan Hasana Kota Banjarbaru." Tesis, Banjarmasin: Institut Agama Islam Negeri Antasari.

Hasan, Noorhaidi. 2012. "Education, Young Islamists and Integrated Islamic Schools in Indonesia." Studia Islamika 19 (1): 77-111. https://doi.org/10.15408/sdi.v19i1.370.

Hefner, Robert. W, ed. 2009. Making Modern Muslims: The Politics of Islamic Education in Southeast Asia. Honolulu: University of Hawai'i Press.

Jannah, Raudhatul. 2017. "Pemikiran Pendidikan Islam Hasan Al-Banna." Journal Analytica Islamica 6 (1): 66-76.

Jaringan Sekolah Islam Terpadu Indonesia. 2021. "Keanggotaan | Jaringan Sekolah Islam Terpadu (JSIT) INDONESIA.” 2021. https://jsit-indonesia.com/samplepage/keanggotaan/.

Jung, Dietrich, dan Ahmed Abou El Zalaf. 2020. Hasan al-Banna and the Modern Muslim Self: Subjectivity Formation and the Search for an Islamic Order in Early Twentieth Century Egypt. Muslim Subjectivities in Global Modernity. Islamic Traditions and the Construction of Modern Muslim Identities. Leiden: Brill.

Kramer, Gudrun. 2009. Hasan al-Banna. London: Oneworld Publications. 
Mahmud, Ali Abd Al-Halim. 2001. Perangkat-Perangkat Tarbiyah al-Ikhwân al-Muslimûn. Diterjemahkan oleh Wahid Ahmadi. Solo: Era Intermedia.

Menshawy, Mustafa. 2020. Leaving the Muslim Brotherhood: Self, Society and the State. London: Springer International Publishing.

Muhtadi, Burhanuddin. 2012. Dilema PKS: Suara dan Syariah. Jakarta: Kepustakaan Populer Gramedia.

Nawawi, Rustam. 2009. "Manajemen Pembelajaran Guru Pendidikan Agama pada SMP Islam Terpadu Qardhan Hasana Kota Banjarbaru." Tesis, Banjarmasin: Institut Agama Islam Negeri Antasari.

Sekolah Islam Terpadu Ukhuwah. 2021. "Profil Sekolah Islam Terpadu Ukhuwah Banjarmasin." Sekolab Islam Terpadu Ukhuwah Banjarmasin (blog). 2021. http://www.ukhuwah.sch.id/.

Shafiyah. 2007. "Model Pembelajaran Terpadu Pendidikan Agama Islam di Sekolah Dasar Islam Terpadu Ukhuwah Banjarmasin.” Tesis, Banjarmasin: Institut Agama Islam Negeri Antasari.

Situmorang, Abdul Wahib. 2007. Gerakan Sosial: Studi Kasus Beberapa Perlawanan. Yogyakarta: Pustaka Pelajar.

Suwito, dan Fauzan. 2005. Sejarah Sosial Pendidikan Islam. Jakarta: Kencana.

Suyatno. 2013. "Sekolah Islam Terpadu; Filsafat, Ideologi, Dan Tren Baru Pendidikan Islam Di Indonesia." Jurnal Pendidikan Islam 2 (2): 355-77. https://doi.org/10.14421/jpi.2013.22.355-377.

Tayeb, Azmil. 2018. Islamic Education in Indonesia and Malaysia: Shaping Minds, Saving Souls. London: Routledge.

Tim Penyusun JSIT. 2006. Sekolah Islam Terpadu, Konsep dan Aplikasinya. Jakarta: JSIT Indonesia.

Willi, Victor. J. 2020. The Fourth Ordeal: A History of the Muslim Brotherhood in Egypt, 19682018. Cambridge: Cambridge University Press.

Yusup, Muhammad. 2017. "Eksklusivisme Beragama Jaringan Sekolah Islam Terpadu (JSIT) Yogyakarta." Religi: Jurnal Studi Agama-Agama 13 (1): 75-96. https://doi.org/10.14421/rejusta.2017.1301-05. 